\title{
Poaching and Negative Implications on the Social Economic Wellbeing of the Local Communities, in Monze District of Southern Province of the Republic of Zambia, (Case of Lochnivar National Park and the Surrounding Game Management Area.
}

\author{
Mike Mulena*, Ramap Binven Bedding \\ Submitted in Part Futilment of the Requirement for the Masters Degree in Criminal Justice, University of Africa \\ *Corresponding Author: Mike Mulena, Submitted in Part Futilment of the Requirement for the Masters \\ Degree in Criminal Justice, University of Africa
}

\begin{abstract}
Wildlife crime is a long standing problem. People have always considered living and non-living species as resources and tradable products used for pure economic gain, wildlife crime involves poachers the study was basically, assessing poaching and negative implications on the social economic wellbeing of the local communities living in and outside Lochnivar National park, the objective was to find out what are the implications of poaching on the social economic wellbeing of the local communities living in and outside Lochnivar National Park?

A sample of 80 purposively sampled were given revised questionnaires to answer comprising questions regarding the negative implications of poaching and prior benefits to local communities before the findings indicated a majority of the participants agreeing to the negative implications of poaching prior benefits before poaching.

It was that recommended that policies and measures be put in place to curb the problem of poaching in Lochnivar National park.
\end{abstract}

\section{INTRODUCTION}

This chapter gives an overview of poaching in general and happenings in Zambia with regard to poaching in our protected areas, regional status of poaching and global standing in terms of the fight against the pandemic. The Lechwe population in the Kafue flats has dropped by 5,000 since 2015, due to increased poaching, with numbers now standing at around 23,306, new data shows. Source (DNPW survey report 2015). In a statement availed by Ministry of Tourism and Arts public relations officer SakabiloKalembwe, a survey conducted by the Department of National Parks and Wildlife (DNPW) and the World Wide Fund for Nature (WWF) in 2015, found the Lechwe population in the Kafue flats drop to 23,306 from 28,711 in 2015.

The status of the Kafue Lechwe is seriously under threat from poaching. According to surveys conducted by the DNPW, with the support of WWF and International Crane Foundation (ICF), the Lechwe population that stood at 28,711 in 2015, now stands at 23, 306 animals. The survey results suggested a Kafue Lechwe population of approximately 38,000, indicating a significant decline in the population of the species from previous counts ${ }^{1}$ (Chansa and Kampamba, 2009).

For instance, in the world Zambia boasts of being the only home to the Lechwe found in Kafue flats thus Lochnivar National Park and Blue Lagoon respectively. The magnificent looking and fleet footed Kafue Lechwe, which stands up to $100 \mathrm{~cm}$ tall and weighs between 70 and $120 \mathrm{kgs}$, is classified as a rare endemic antelope. The species is listed as vulnerable by the international Union for Conservation of Nature (IUCN) due to its status. It is regarded as a protected animal in Zambia under the Wildlife Act Number 14 of 2015, of the laws of Zambia).

Minister for Southern Province, Honourable 2 Edify Haamukale, M.P in 2018, warned that unless poaching is brought under control many species on the Kafue Flats face extinction (Zambia Daily

\footnotetext{
${ }^{1}$ Kampamba \& Chansa, (2009)

${ }^{2}$ Dr. Edify, Haamukale, MP (2018)
} 
Poaching and Negative Implications on the Social Economic Wellbeing of the Local Communities, in Monze District of Southern Province of the Republic of Zambia, (Case of Lochnivar National Park and the Surrounding Game Management Area.

Mail, 22 June 2017). It is however, worrying that this valuable natural resource has been declining at an alarming rate due to poaching in the Kafue flats. Early 2018, the southern Province Minister Dr. Edify Haamukale revealed that a scam was unearthed where a cartel of Senior Civil Servants, traditional leaders and employees of the Department of National Parks and Wildlife officers have been poaching 15 to 20 Kafue Lechwes per day, which meant that the country was losing 5,475 animals per year.

At regional level the rapid population growth and poverty have also resulted in several problems for wildlife conservation in the sub region. The world population data sheet projects that Africa's population will double to about 2.4 billion by $2050^{3}$ (Population Reference Bureau, 2013). This rapid population growth has several implications for wildlife conservation. Firstly, there is a growing pressure on very limited arable lands for subsistence farming which pushes farmers further into marginal environments and wildlife habitats.

Another problem is that the lack of legal backing and enforcement of agreed upon issues between the local communities, government and park authorities. Many of these parks were established without any legal agreement with residents communities ${ }^{4}$ (Linsey, et al, 2014). In the few cases where legal agreements were entered into to provide resident communities access to resources and economic benefits from the community based conservation approach, the terms of these agreements were never fulfilled, creating animosity and suspicion of displaced resident rural communities towards wildlife conservation efforts ${ }^{5}$ (Muhumuza and Balkwill, 2013).

Illegal hunting or rather poaching so to say broadly refers to illegal taking of wildlife and wildlife resources ${ }^{6}$ (Musgrave et al. 1993; Eliason 2003; Mc Skimming and Berg 2008). Stigmatized as theft and animal cruelty or celebrated as rebellion against oppressive laws, the crime is a global concern for wildlife conservation, including endangered species ${ }^{7}$ (Manelet al. 2002; Gavin et al. 2010; Kaczenskyet al. 2011; Ayling 2013). Responses to illegal hunting have resulted in long-term warfare between anti-poaching paramilitary units and local hunters in protected areas such as Kruger National Park in South Africa and Bandipur National Park in India. Research has shown that the clandestine and often community sanctioned nature of the crime means that illegal hunting has regularly gone undetected ${ }^{8}$ (Thompson 1975; Green 1990; Eliason 2008; Crow et al. 2013; Gangaas et al.2013).

Public support for illegal hunting has additionally been shown to be increasing in socio political contexts in which conservation policy is seen as unfair and lacking in legitimacy, such as Finland ${ }^{9}$ (Peltolaet al. 2013). During 2013 in South Africa, more than 1000 rhinos were poached and 606 of these killings occurred in Kruger National Park (Department of Environmental Affairs, Republic of South Africa, 2014). Dwindling elephant herds and rhinos is not the only problem faced by wildlife. Decline in the population density of Buffaloes, Eland, Impala, reedbuck, warthog and water buck were in part, due to poaching activities in the Katavi National Park and Rukwa Game Reserve in Western Tanzania ${ }^{10}$ (Caro et al.2013, Martin and Caro, 2013). To minimize the appeal of illegal hunting, the Kenyan parliament enacted a law that substantially raised the fines levied against arrested poachers to $\$ 120,000$ coupled with 15 years incarceration.

Before the enactment of the law, punishments meted out to the offenders amounted to no more than a slap on the wrist. As a result of poaching, Kenya's elephants declined from 160,000 in 1960 to 16,000 in 1989 and currently there are only about 3,850 elephants and 1,025 rhinos left in the country (Messenger, 2013). Population of the sable antelope, located in Kenya, has fallen to an estimated 70 animals over the last three decades ${ }^{11}$ (Musyoki et al 2012).

\footnotetext{
${ }^{3}$ Population Reference Bureau, (2013)

${ }^{4}$ Linsey, et al.2014.

${ }^{5}$ Muhumuza \& Balkwill, 2013.

${ }^{6}$ Musgrave et al. 1993, Eliason 2003, MC Skimming \& Berge 2008.

${ }^{7}$ Manel et al. 2002, Gavin et al. 2010, Kaczensky et al. 2011, Ayling 2013.

${ }^{8}$ Thompson 1975, Green 1990, Eliason 2008, Crow,et al.2013, Gangaas et al. 2013.

${ }^{9}$ Peltola et al. 2013.

${ }^{10}$ Caro et al 2013, Martin \& Caro, 2013.

${ }^{11}$ Musyoki et al 2012.
} 
Poaching and Negative Implications on the Social Economic Wellbeing of the Local Communities, in Monze District of Southern Province of the Republic of Zambia, (Case of Lochnivar National Park and the Surrounding Game Management Area.

The costs of poaching on wildlife are many and varied and often include the inhibition of population growth, collapse of geographical ranges and ultimate extinction of species ${ }^{12}$ (Woodroffe, Thirgood, and Rabinowitz, 2005) and consequently, wildlife tourism development efforts. Illegal animal poaching is a growing crisis across the globe and an increasing interest to the local communities. In 2012, poaching levels in Africa were at their highest since detailed record keeping began in 2002, and 2011, broke the record for the most illegal ivory seized worldwide totaling 38.8 tones ${ }^{13}$ (Gettleman, 2012). In November of 2012, former Secretary of state Hilary Clinton addressed the intelligence community stating that:

Trafficking relies on porus borders, corrupt officials, and strong networks of organized crime, all of which undermine our mutual security, lam asking the intelligence community to produce an assessment of impact of large scale wildlife trafficking on our security interests, so we can fully understand what are we up against (secretary Clinton Declares War on Wildlife Traffickers, 2012, para.20). President Obama has also ramped up awareness for animal poaching, as shown during his first trip to Africa in July 2013. Among other key initiatives, the trip included a \$10 Million USD commitment to tackle the growing problem threatening to completely wipeout, elephants, rhinos, and other endangered animals ${ }^{14}$ (Reinl, 2013).

As a result of this poaching epidemic, described by Richard, G. Ruggiero, an official with the United states Fish and Wildlife Service, We are experiencing what is likely to be the greatest percentage loss of elephants in history ${ }^{15}$ (Gettlemman, 2012a, para.21).This has led conservationists to make claims that the mass killings in Africa are as bad or worse than the 1980's when poachers eliminated over half of African's elephants before the international ban on the commercial ivory trade was implemented (Gettleman, 2012a). As noted by ${ }^{16}$ Karimi (2013) drastic measures have taken to create awareness, such as the destruction of 6 million tonnes of seized ivory compiled over the past 25 years.

\subsection{Statement of the Problem}

The problem statement centers on poaching and the negative implications on the social economic wellbeing of the local communities, living in and outside Lochnivar National Park and the surrounding game management areas. The status quo in terms of poaching was alarming going by the statistical data on the survey which was conducted by the Department of National Parks and Wildlife in 2015, which revealed that Kafue Lechwes stood at 28,711 in 2015, and has drastically reduced to 23,306. (Source Department of National Parks and Wildlife (DNPW survey report of 2015).

\subsection{Purpose of the Study}

It was important to identify the inadequacies that exist in the fight against poaching, in order for the government of the republic of Zambia, through the Department of National parks and Wildlife to devise a proper mechanism that would prevent and control poaching in Lochnivar National park and the surrounding protected areas. I believe a proper mechanism in the fight against poaching, would improve the levels of thinking in the local communities with regard to matters of wildlife conservation in the area.

\subsection{Research Question}

What were the negative implications caused by poaching on the social wellbeing of the local communities in Lochnivar National Park?

\section{LiTERATURE REVIEW}

The Lechwe population in the Kafue flats thus Lochnivar National Park has dropped by 5,000, since 2015 , due to increased poaching, with numbers at 23,306 , new data shows. In a statement availed by Ministry of Tourism and Arts public relations officer SakabiloKalembwe, a survey conducted by the Department of National Parks and Wildlife and the World Wide Fund for Nature (WWF) found the

\footnotetext{
12 Woodroffe, Thirgood, \& Rabinowitz, 2005.

${ }^{13}$ Gettleman, 2012.

${ }^{14}$ Reinl, 2013.

15 Gettleman 2012a, para 21.

${ }^{16}$ Karimi 2013.
} 
Poaching and Negative Implications on the Social Economic Wellbeing of the Local Communities, in Monze District of Southern Province of the Republic of Zambia, (Case of Lochnivar National Park and the Surrounding Game Management Area.

Lechwe population in the Kafue National Park drop to 23,306 from 28,711 in 2015. The status of the Kafue Lechwe is seriously under threat from poaching.

Preliminary reports of the 2018, Kafue Lechwe population count on the flats indicates a critical situation for the endemic species, which has recorded a decline of approximately 5,000 animals in three years. According to surveys conducted by the Department of National Parks and Wildlife (DNPW), with the support of World Wide Fund for Nature (WWF) and International Crane Foundation (ICF), the Lechwe population that stood at 28,711 in 2015, now stands at 23, 306 animals.

Given the rapid rise of rhino poaching in South Africa since 2008, Milliken and Shaw (2012) is an important read. The authors in depth analysis of markets for rhino horn and the various poaching methods used, gives a well-rounded, well-informed view of the problem. Although poaching has long been considered a conservation issue, the criminal element has attracted the attention of criminologists. The result has been the introduction of conservation criminology by Gibbs, et al. 2009, research on the criminal opportunity structures of poaching by Lemieux 2014 and the wildlife trade by Schneider 2012, and the discussion in Wyatt 2013 of the problem from a green criminology perspective. The well-researched easy to read document provides up to date information and eight useful case studies. Fa, et al. 2005 and Lindsey, et al. 2013 focus on bush meat poaching in the forests and savannas of Africa respectively.

Wildlife crime (poaching) has been a conservation scourge for decades. Poaching and illegal harvesting, particularly in Africa, continues to devastate wildlife populations, threatening the survival of rhinos, elephants, pangolins, rosewoods and a wide variety of other species. The illegal wildlife trade, now the fourth largest illicit transnational activity in the world, is the fuel that drives the wildlife crime fires. Continuing consumer demand, largely from Asia, for increasingly rare horns, ivory, bones, skins, and precious timber is driving unprecedented wildlife population declines. Wildlife crime is on the rise throughout sub Saharan Africa and, with over 20 national parks and 34 game management areas, Zambia is not immune. Source conservation south Luangwa (CLS) report 2014.

\section{Methodology}

\subsection{Study Sample}

The study sample was about 80 respondents from selected communities in Chief Haamusonde and Choongo, were sampled from a population of above 21,000 in the area, who were living approximately $300 \mathrm{~m}$ away from Lochnivar National park, this was the target population for the study. Generalization of respondents was taken care of by the researcher when doing the sampling. The selection of the sample representative of the population is essential ${ }^{17}$ (Karasar, 1999).

\subsection{Sampling Technique}

The researcher used purposive sampling, according to ${ }^{18}$ Leedy and Ormrod (2005) purposive sampling is meant for a particular purpose, where people or units are chosen who are typical of a group or those that represent a diverse perspective on an issue. They further elucidate that purposive sampling be very appropriate for certain research problems and that the researcher always provide a rational explanation for choosing this sampling technique. The justification for using this sampling techniques is that:

- It is reliable

- It is cost effective

- It gives opportunity for respondents to be selected

- It is easy and convenient method of sampling

\footnotetext{
${ }^{17}$ Karasar, 1999.

${ }^{18}$ Leed \& Ormrod 2005.
} 
Poaching and Negative Implications on the Social Economic Wellbeing of the Local Communities, in Monze District of Southern Province of the Republic of Zambia, (Case of Lochnivar National Park and the Surrounding Game Management Area.

\subsection{Data Collection Instruments}

The study used a revised questionnaire administered to participants that consented to part of the study. The questionnaire included questions such as

1. Where the local communities in Chief Haamusonde and Choongo benefiting from wildlife resources before poaching

2. Where the local communities negatively affected by poaching in Lochnivar National Park

3. Do you agree that poaching has an implication on the social wellbeing of the local communities around Lochnivar National Park?

\subsection{Ethical Consideration}

The study ensured that ethical issues of research were taken into consideration, such as confidentiality, obtaining consent from the informants throughout the field work, explaining the study benefits of research to the participants' rights in the whole process

\section{FINDINGS AND DISCUSSION}

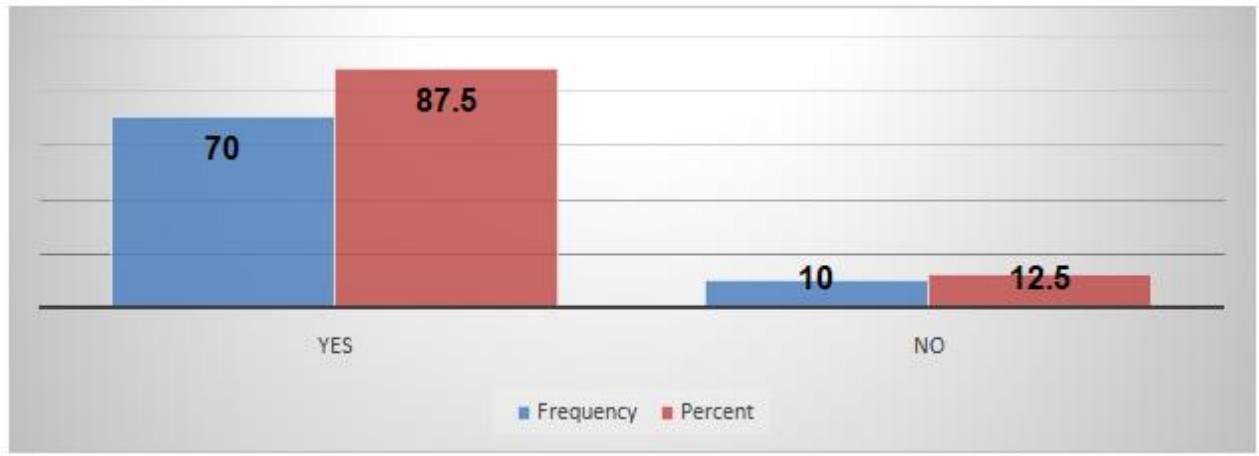

Figure1. Wether People In The Community Have Been Benefiting from Wildlife Resources Before Reduction In The Wildlife Population - Source Data Collected During My Research In Monze District.

The study endeavoured to first and foremost establish whether the community within and close to Lochnivar National Park were benefiting from wildlife resource, before the current reduction of wildlife population in the said National Park. Figure 1 above illustrates that about $87.5 \%$ of the respondents were in the affirmative while about $12.5 \%$ were not. The findings showing the majority in the affirmative could be considered as a clear confirmation on the fact that the communities within and near the national park have been benefiting greatly from the wildlife resource and that they do realize the effects of the reduction in wildlife population

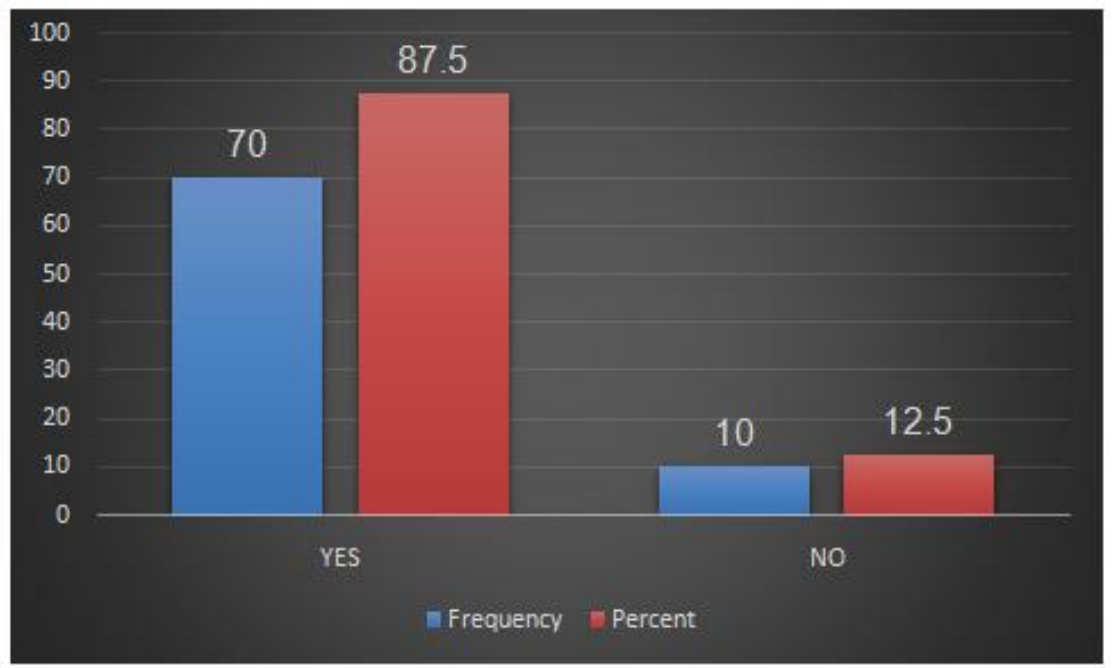

Figure2. Whether Community Has Been Affected Negatively Due To Poaching - Source Data Collected From the People. 
Poaching and Negative Implications on the Social Economic Wellbeing of the Local Communities, in Monze District of Southern Province of the Republic of Zambia, (Case of Lochnivar National Park and the Surrounding Game Management Area.

The figure shows that generally the community has been affected negatively due to poaching, with $87.5 \%$ of the respondents confirming the same and $12.5 \%$ not in the affirmative. Some discussions with key informants indicate negative effects among others to include loss of jobs from Safari hunting activities and Lodges who have down sized their human resource. This has been due to reduced rates of tourism as most exciting wildlife has gone extinct coupled with a general reduction in wildlife population.

Figure3. Opinions On Whether Poaching Has A Negative Implication On The Social Economic Well Being Of Communties Living In And Outside Lochnivar Park - Source Data Collected From The People

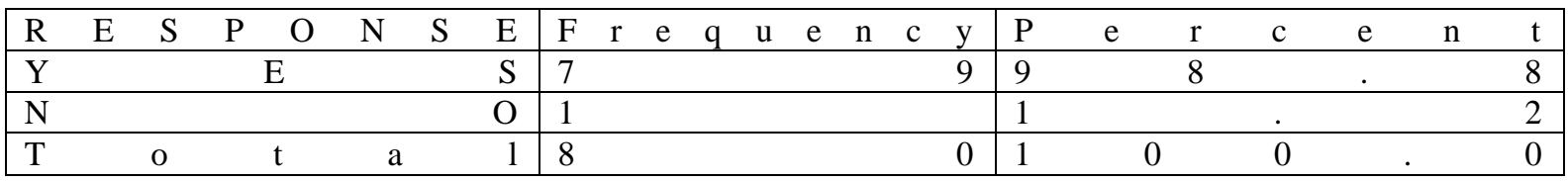

To determine whether community members within and near the Lochnivar National park realize the negative implications of poaching on their economic social wellbeing, the findings reveal that $99 \%$ of the respondents felt that it had, with only $1 \%$ not in the affirmative ( Refer to Table 5 above). The stated findings would be linked to the earlier stated findings on estimates of community members in support of wildlife conservation. Generally it can be established that despite a known fact that poaching has adverse effects on the economic social wellbeing of communities, there seem to be lower estimates of those in support of wildlife conservation

\section{CONCLUSION AND RECOMMENDATIONS}

Based on the above findings it can be concluded that poaching of wildlife species was real in Lochnivar National Park, and needs a political will to avert the scourge. It was found that poaching in Lochnivar National park had a serious implication on the social economic wellbeing of the local communities, in that the tourism industry has collapsed in the park, due to poaching, and this has impacted on the livelihood of the people who depended to be employed in this industry, like it used to be during the early 1990s, when some lodges were up and running in the park, which is no longer the case now.

Thus I would recommend the following:

- To devise new policing models such as the intelligence led policing to cope up with new technology in curbing poaching.

- To improve on policies governing wildlife conservation like amending the wildlife Act which was viewed as a menace to the local communities,

- Fight corruption amongst the wildlife police officers based in Lochnivar National park permitting illegal poaching.

\section{BIBLIOGRAPHY}

[1] Abernsperg-Traun, M., C. O'Criodain and D. Roe (eds) (2011) CITES and CBNRM: Proceedings of an international symposium on "The relevance of CBNRM to the conservation and sustainable use of CITESlisted species in exporting countries" (London: IIED).

[2] Adams, J. S. and McShane, T. O. (1992) the Myth of Wild Africa: Conservation without Illusion (Berkeley, CA: University of California Press).

[3] Adams, W.M. (2009) 'Sportsman's shot, poacher's pot: hunting, local people and the history of conservation' in Dickson, B., J. Hutton and Adams, W.M. (eds) Recreational Hunting, Conservation and Rural Livelihoods: Science and Practice (Chichester: John Wiley and Sons) pp. 127-140.

[4] Adams, W. M. (2004) Against Extinction: The Story of Conservation (London: Earthscan)

[5] Adams, W. M. and Infield, M. (2003) 'Who is on the gorilla's payroll? Claims on tourist revenue from a Ugandan National Park', World Development, 31(1): 177-90

[6] Adams, W. M. et al. (2004) 'Biodiversity conservation and the eradication of poverty?', Science, 306: $1146-9$

[7] Agrawal, A. (2001) Common property institutions and sustainable governance of resources. World Development 29 (10): 1649-72. 
Poaching and Negative Implications on the Social Economic Wellbeing of the Local Communities, in Monze District of Southern Province of the Republic of Zambia, (Case of Lochnivar National Park and the Surrounding Game Management Area.

[8] Agrawal, A. and Gibson, C. C. (1999) 'Enchantment and disenchantment: The role of community in natural resource conservation', World Development, 27(4): 629-4

[9] Ashley, C., D. Roe and H. Goodwin (2001) Pro-Poor Tourism Strategies: Making Tourism Work for the Poor - A review of experience (London: ODI).

[10] Ajzen, I. (1991) the theory of planned behavior. Organizational Behavior and Human Decision Processes 50, 179-211.

[11] Ajzen, I., Fishbein, M., (1980) Understanding attitudes and predicting social behaviour. Prentice-Hall, Englewood Cliffs, New Jersey 07632.

[12] Alvard, M.S., et al. (1997) The sustainability of subsistence hunting in the neotropics. Conservation Biology 11(4):977-82.

[13] Barber, Meyer, S.M. (2010). Dealing with the clandestine nature of conservation Biology 24(4), 918-923.

[14] Balis, K, Honey, Roses, J., Borner, J,Corbera, Ezzine de Blas, D, Frraro, P,J, et al.(2016). Mainstreaming impact evaluation in nature conservation. Conservation Letters, $9,58-64$.

\section{AUTHORS' BIOGRAPHY}

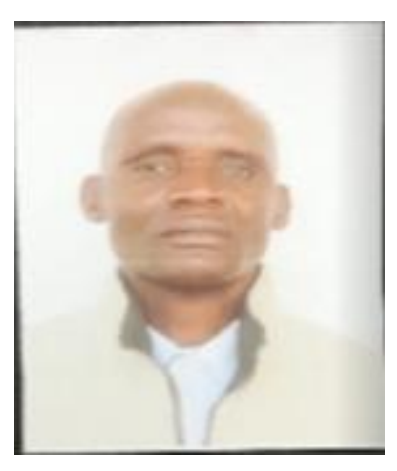

University of Africa

I am a Zambian National aged 52, working for the Department of National Parks and Wildlife as Senior Intelligence Officer based in Lusaka.

\section{ACADEMIC QUALIFICATION}

Holder of a grade twelve (12) Certificate

\section{PROFFESSIONAL QUALIFICATION}

2018 - 2020: Completed Masters Degree in Criminal Justice through University of Africa

2013 - 2016: Completed a Bachelors Degree in Criminal Justice through

2009 - 2010: Obtained a Diploma in Public Administration through the University of Zambia

2006 - 2008: Obtained a Diploma in Security and Risk Management through Central Africa

Correspondence college registered college under TEVETA.

2000 - 2001: Obtained a Diploma in Private Detective and Security Management through

Lusaka Institute for Business Studies registered college under TEVETA.

2006: Obtained a Certificate in Psychosocial Counseling through University of Zambia.

1990: Obtained a Certificate in Wildlife at Chunga College of Wildlife Management

Citation: Mike Mulena, Ramap Binven Bedding. "Poaching and Negative Implications on the Social Economic Wellbeing of the Local Communities, in Monze District of Southern Province of the Republic of Zambia, (Case of Lochnivar National Park and the Surrounding Game Management Area." International Journal of Humanities Social Sciences and Education (IJHSSE), vol 7, no. 10, 2020, pp. 36-42. doi: https://doi.org/10.20431/2349-0381.0710004.

Copyright: (c) 2020 Authors. This is an open-access article distributed under the terms of the Creative Commons Attribution License, which permits unrestricted use, distribution, and reproduction in any medium, provided the original author and source are credited. 